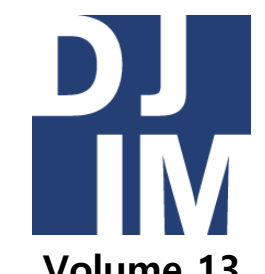

Volume 13

Spring

2017

djim.management.dal.ca |

\title{
AIDS Represented Within the Media
}

Emily Maclsaac

School of Information Management, Dalhousie University

\begin{abstract}
This paper is about the media portrayal of HIV/AIDS within America primarily during the first two decades of the epidemic. This paper will outline different types of media and how they portrayed those affected with this illness. The news mainly indicated that those who were gay, intravenous drug-users, or haemophiliacs were the key demographic to contract HIV/AIDS. Many began to feel invincible to HIV/AIDS because the media was highlighting specific demographics of people. The Center of Disease Control's (CDC) statistics indicate that gay men were not the 'high risk' population, but young African and Hispanic adults were at highest risk. The purpose of this paper is to indicate that the media swayed public opinion, as seen in Kathleen Farrell's study, which spread misconceptions about how this illness was contracted, transmitted, and how HIV positive individuals led their lives.
\end{abstract}

\section{AIDS Represented Within the Media}

News network channels, television, and movies have a substantial influence on people's everyday lives. These outlets are information settings that enlighten viewers about society, and ultimately show people how to navigate through society by influencing their opinions. In the 1980s, HIV/AIDS became an epidemic and information released by the media taught society how to think about this disease regardless if the information was incorrect. Most notably, in the first two decades of the epidemic, the media indicated that HIV/AIDS was a "gay disease" because the virus struck the gay communities of New York and Los Angeles first. Since this illness was not fully understood at the time, this caused many cases to be misdiagnosed because medical professionals were unaware that this illness was spread through bodily fluids. This meant that blood transfusions and the sharing of unsanitary or used needles ran the risk of transmitting the illness. Therefore, hemophiliacs, often needing transfusions more frequently, and intravenous drug users were particularly in danger of being exposed. Yet if people did not fall into these specific categories that the media portrayed, it suggested that the white, heterosexual, nondrug user did not have to worry about 
contracting this virus and could feel invincible (Hart, 2002).

At the time, the media was only publicizing those who died from this illness, while neglecting to inform people of any preventative measures for HIV/AIDS despite the increased amounts of cases being reported. The amount of news coverage regarding HIV/AIDS peaked in 1987 with almost six thousand stories (Brodie et al., 2004). That being said, Brodie et al., state that "the number of stories released does not correlate with the number of people actually diagnosed with HIVIAIDS". In 1992 and 1993 there were 80,000 new cases but the news stories about the virus were falling to the wayside (Brodie et al., 2004). This paper primarily explores news, television, film, and the musical Rent to understand media trends during the first two decades of the AIDS epidemic in the United States. Ultimately, white gay men were thought to be the key demographic for contracting this illness and were seen as a scapegoat within the society, but reports from the Centers for Disease Control and Prevention (CDC) counter these claims (Hart, 2002). The information released within these 20 years proves that the negative mentality surrounding the virus was socially constructed as a result of the media highlighting a specific community whom were thought to be the sole carriers of this illness. The negative mentality surrounding this virus originated as a result of the media creating and reinforcing certain misconceptions which was mainly damaging for the gay communities. However, while this information was mostly misinformed, some media began to rectify fallacies - especially as HIV/Aids began to become more understood.

\section{Epidemiology of AIDS}

HIV/AIDS is a relatively new illness to epidemiology as it had its origins in the twentieth century. The origin of HIV/AIDS can be traced back to the 1920s in the Democratic Republic of the Congo (DRC) via the preparation of bush meat, meat from wild animals (Locatelli and Peeters, 2012), specifically from monkeys that carried the Simian immunodeficiency virus (Gallagher, 2014). As soon as this virus was in one person's bloodstream from preparing the bush meat, it could be transferred to others via bodily fluids (Gallagher, 2014). There were two ways it began to spread: One was public health employees, who were vaccinating African people against infection and disease, but did not use sanitary needle practices to prevent the spread of the HIV virus (Gallagher, 2014). The second was the railway network, which allowed people to move across the African continent with ease (Gallagher, 2014), increasing the chance of people contracting the virus across a wider geographical range. The illness was isolated to the African continent until Haitians were working in the DRC in the 1960s. Haitians contracted HIV from residents of the DRC, which resulted in the illness moving to the South Americas (Netburn, 2016). The virus was then carried from Haiti to the United States as a result of the flourishing sex tourism within Haiti, which is how Americans came into contact with HIV in America circa 1970/80s (Pepin, 2011). When the initial cases of HIV were reported in the United States, the virus stumped the medical profession as there was a lack of knowledge regarding the illness - since HIV patients presented similar symptoms and were not responding to medications.

The epidemiological connection regarding the HIV/AIDS virus travelling from the DRC 
to Haiti to the United States is relatively new. Gaetan Dugas, a French-Canadian flight attendant, was thought to be responsible for spreading the illness along the North American continent. It was argued that Dugas was the sole person responsible for spreading HIV/AIDS because he was originally misdiagnosed, at the latter end of the 1970s, with Kaposi's Sarcoma virus (KS) (Shilts, 1987). Even when his true diagnosis was discovered in 1981, Dugas continued to have many sexual partners, with this, Richard Shilts portrays Dugas's journey with HIV/AIDS in a negative light (1987). Dugas was angry with being HIV positive and did not believe that this illness could be spread via sexual encounters, so he continued to have sex with men, thus spreading the virus (Shilts, 1987). Shilts, along with others, essentially blame Dugas for spreading the illness through gay communities within Canada and the United States (1987). Shilts described that epidemiologists sought answers from newly diagnosed AIDS patients in Los Angeles to understand how they might have contracted it (Shilts, 1987). Shilts (1987) writes within his work that when these epidemiologists tallied their records to discovered that, "Of the 19 cases of [AIDS] in Los Angeles (LA), four had sex with Gaetan Dugas. Another four cases, meanwhile, had gone to bed with people who had had sex with Dugas." (p. 130).

As a result of Dugas' sexual encounters, he was deemed "Patient Zero" (Netburn, 2016). The CDC meant to call him "Patient O" to stand for 'Out of California' (Netburn, 2016) but a zero replaced the ' $\mathrm{O}$ ' to indicate that Dugas was the first to have the illness in North America. Nevertheless, these names were assigned to Dugas to indicate that he was spreading HIV/AIDS across North America (Gallagher, 2016). As of October
2016, Dugas' reputation was redeemed when the scientific community confirmed that he was not responsible for spreading the HIV/AIDS virus across the continent. Michael Worobey, an evolutionary biologist at the University of Arizona, confirmed that Dugas was one of thousands who were misdiagnosed with HIV/AIDS in the late 1970s (Netburn, 2016). Deborah Netburn (2016) articulated that

To see if any of the men in the hepatitis B study [dating back to the first decade of the epidemic] had contracted HIV, a different group of researchers analyzed the New York City samples and found that, indeed, $6.6 \%$ of them contained HIV antibodies. Inspired by this work, Worobey and his team did a similar test for the West Coast samples and discovered HIV antibodies in $3.7 \%$ of them. (para. 7)

This study proved that Dugas was one of many who were incorrectly diagnosed but also explains the trail of how this illness spread from the DRC in the 1930s, to Haiti in the 1960s, and then to America by the 1970s (Netburn, 2016). Worobey even notes that HIV/AIDS was in New York before it travelled to Los Angeles, and ultimately to the rest of the world - which caused the HIV/AIDS pandemic (Netburn, 2016). Dr. Beatrice Hahn, a professor of medicine, notes that Dugas may not have been the first with this illness in North America, but he was the only individual to carry a specific strand of HIV (Netburn, 2016). She explains that Dugas was essentially deemed "Patient Zero", despite the CDC being aware that he was the $57^{\text {th }}$ person to be diagnosed with HIV during a time of uncertainty within the medical community (Netburn, 2016). Netburn articulates that Dugas' identity was only 
known within the medical community, but then Shilts (1987) openly wrote about Dugas in his book, And the Band Played On, where the Canadian flight attendant was demonized. Within this book, Shilts (1987) indicates that people warned Dugas about having sex because he was spreading the AIDS virus. However, Dugas did not listen because he was convinced he had "gay cancer" and it could not be spread via sexual activities. Now that the background information has been explained, the next section of this paper will discuss how the media portrayed individuals with HIV/AIDS during the first two decades of the AIDS epidemic.

\section{HIV/ AIDS in the News}

AIDS was originally seen as a "gay disease," and before AIDS was the approved acronym, some scientists thought this should be called GRID or Gay-Related Immune Deficiency (Shilts, 1987). It was quickly realized that the virus did not distinguish between sexual orientation (Shilts 1987). In the early decades of the AIDS epidemic, media underrepresented the seriousness of the illness as minimal stories that were released about those affected. New York and Los Angeles were discussing the unknown elements of AIDS two or three years prior to the media's broadcasted information. In 1981 , $83 \%$ of stories regarding AIDS, followed the CDC research by informing audiences about the "Gay Pneumonia" (Brodie et al., 2004). In 1982, media reports about this type of pneumonia were down by $50 \%$ (Brodie et al., 2004). This was early in the epidemic, as the CDC was still researching what caused immune systems to be compromised. Since the public did not understand the virus in the early years of the epidemic, a spike in the media did not occur until 1985 with another exponential spike in
1987 (Brodie et al., 2004). S urprisingly, these peaks in the media do not correlate with the spike in those diagnosed as there were 80,000 diagnoses in 1992-3 (Brodie et al., 2004). News titles were advocating that HIV/AIDS was an illness that primarily affected the gay population in the United States.

In 1982, an article in the Wall Street J ournal titled "New, Often-Fatal Illness in Homosexuals Turns up in Women, Heterosexual men" (Shilts, 1987, p.126) was printed because the reporter of this article found 23 heterosexual intravenous drug users had been diagnosed with AIDS (Shilts, 1987). Since the news only reported gay men and drug users as HIV positive, it created a mask that caused people, who were neither gay nor a drug addict, to feel safe. Many in society thought they were going to be unaffected and could let the entire epidemic pass. In 1987, there was a story in the New York Times with the headline "Family in AIDS Case Q uits F lorida Town After House Burns." This story outlines the Ray family who had four hemophiliac children, and when using blood clotting drugs, they contracted AIDS (New Y ork Times, 1987). The residences of Arcadia, Florida were not pleased to have children infected with AIDS in their community (New York Times, 1987). The Ray children were boycotted out of their local school and then their family home caught fire (New York Times, 1987). Luckily, everyone survived the fire but the family admitted to the New York Times journalist that they were leaving Arcadia because they felt their lives were in danger (New York Times, 1987). The retaliation from the Arcadia community was a result of the widespread stigmatization of AIDS, and it was problematic for journalists to discuss the true facts regarding this sexually transmitted disease. 
Elinor Burkett (1995) wrote that it was difficult for journalists to talk about AIDS because it involved anal sex or indicated that young people were having sex. Neither of these topics appealed to the public (Burkett, 1995). Burkett (1995) also noted that "politics, greed and utter stupidity were making a mockery of the war against the epidemic. AIDS never got a chance to be simply a disease" (p. 14). This quote is indicative that AIDS was not simply a researchable illness that could eventually be cured, but was connected to sexual promiscuity and the gay community; both often seen as immoral. It is evident that news articles allowed AIDS to hide behind a specific type of person - particularly in the early years of the epidemic. In 1992, one of the ground-breaking stories within the AIDS epidemic was when Magic Johnson announced he was HIV positive (Brodie et al., 2004). When this news broke, it was $16 \%$ of the news stories of that year (Brodie et al., 2004). The media is responsible for the boundaries and stigmas society placed on individuals who have HIV/AIDS.

Kylo-Patrick R. Hart (2002) expressed that societies' ideas surrounding HIV/AIDS are socially constructed because of the media's portrayal of those with this illness. In Hart's (2002) article he indicates that:

The social-construction perspective maintains that contemporary historical reality does not exist in any tangible form as a "truth" waiting to be discovered; instead, it is created through the actions of the most influential social actors (including media professionals) in the same society as they compete with one another over the appropriate construction of contemporary social conditions. (para. 5)
This quote shows that the information disseminated to society at the time of the AIDS epidemic in America was essentially dictating how this illness was viewed. Hart goes on to say that no matter how the media attempted to correct the information that was previously stated about this illness, it did not help as AIDS had already been ascribed a specific way (Hart, 2002). Kathleen Farrell's article "HIV on TV: Conversations with Young Gay Men" indicates that news regarding AIDS caused society to be anxiety ridden; people even thought this virus could be spread via public toilet seats (Farrell, 2006). The mass misunderstanding about how and to whom this illness could be transferred was only exacerbated when tabloids such as the cover of Life Magazine proclaimed, "Now No One is Free from AIDS" to readers in 1985 (Hart, 2002, para. 1). This title was released when Rock Hudson, a Hollywood actor, discovered that he was HIV positive (Hart, 2002). This news was shocking to the rest of society because Hudson was a straight, nondrug user which was not the key demographic for the AIDS Virus (Hart, 2002). Hart indicates that Life Magazine should not have had this headline, as AIDS was ravaging the gay communities of New York and Los Angeles for more than five years, and there was information about this virus available to the public (Hart, 2002).

News is a way for the general population to gain an understanding about the epidemic at large, but it might not be as accessible to a younger audience. The representation of HIV/AIDS on television shows or in movies is a way to reach this audience, but it can distort their views on the topic depending on how it is presented. The next section will primarily discuss how gay men are represented in these two mediums. 


\section{AIDS represented in television and movies.}

The Cable News Network (CNN) was the first to mention AIDS in 1981. It was not until three years later that St Elswhere, the first television show to feature a character with AIDS, aired. Kathleen Farrell (2006) notes that there was a hiatus in "gay-themed AIDS drama[s]" as the next one did not appear until 1985 (Farrell, 2006, p.195). It was thought that if characters with AIDS were included then "gay rights" or "right-wing" activists would speak out about the epidemic within the media (Farrell, 2006, p.195). Essentially, networks were restricting information regarding AIDS in order to supress activist groups who may vocalise their opinions regarding HIV/AIDS. Plus, these networks wanted the news channels to have a dialogue about AIDS, as they were already showing these patients dying from the illness (Farrell, 2006). In 1985, the National Broadcasting Company (NBC) TV Movie An Early Frost was released, it includes a discourse about a young man who is HIV positive and his diagnosis "outs" him to his family (Farrell, 2006). It is noted that this film was nominated for an Emmy Award after receiving excellent ratings when it was released - this is an exceptional feat for a film with a gay male, HIV positive character (Farrell, 2006). However, instead of portraying the main character as living a full life despite contracting HIV, he died by the end of the movie and was a "victim of HIV" (Farrell, 2006). This film is also limiting because it essentially focuses on how the family reacted to having a gay, HIV positive relative and not about the character dealing with his illness (Farrell, 2006). After the 1980s there were fewer shows featuring characters with AIDS, but Hollywood producers were still creating films with characters that were HIV positive such as Philadelphia (1993) and The Hours (2002) (Farrell, 2006). There was a prominent television show, Queer as Folk, that had many seasons and a main character was HIV positive (Farrell, 2006).

Kathleen Farrell's article "HIV on TV: Conversations with Young Gay Men," was written to achieve a greater understanding of how gay and bisexual youth understood the illness (Farrell, 2006). To do this, she conducted a study in 2006 focusing on the media's portrayal of characters with HIV/AIDS. Since AIDS was no longer explicitly feared at this time, but it was still important for people to be aware of the illness and how to protect oneself from it. Farrell (2006) even notes that her participants, male university students, did not know anyone living with AIDS so they gained information about the illness from movies and television (Farrell, 2006). Ferrell's study focuses on her test subjects' reactions to the television show, Queer as Folk (2001). This is a reaffirming show that portrays gay people in a normal light, dealing with everyday problems; homophobia, and HIV/AIDS. Ferrell notes in her article that the script of this show includes:

Stories of its leading roles being tested for the virus, an episode where a good friend of a main character dies of AIDS, an episode centered on raising money for an AIDS-care organization, and several other explicit references to condom use to protect from sexually transmitted diseases, including HIV. (Farrell, 2006, p. 198).

One character within the show has been living with HIV for a decade. This is enlightening for all audiences because it 
indicates that those diagnosed with HIV can live normal lives (Farrell, 2006). The characters on Queer as Folk were much different than shows that were produced in the 1980s because if a character was diagnosed with HIV it was very dramatic, and the character was likely to die (F arrell, 2006). Whereas, characters on Q ueer as Folk have diverse relationships; two characters fall in love, despite one person being HIV positive (Farrell, 2006). This show was groundbreaking because the characters demonstrated to viewers that they could happily live their lives regardless of their diagnosis.

With the framework that Queer as Folk provided, Farrell wanted undergraduate gay and bisexual males to watch the episodes and then discuss its messages (Farrell, 2006). When analysing the discussion during Farrell's study, many thought HIV/AIDS was intimidating or unnerving rather than an illness that people can cope and live with (Farrell, 2006). The students mainly had this consensus because an individual must completely change their habits as a result of this illness (Farrell, 2006). It was also expressed that many of the test subjects would not continue a romantic relationship if their partner was HIV positive as it would be putting themselves at risk (Farrell, 2006). One of the participants contended that HIV positive individuals can be in a "loving, caring relationship regardless of HIV status" (Farrell, 2006, p. 204). Many of the participants agreed that their sexual education at school failed them (Farrell, 2006). While many agreed that they were told simple facts about the virus, but there was a lack of humanism associated with it and there was a sense of hopelessness in the prospect of living with HIV (Farrell, 2006). One participant stated that he learned that "people with HIV [were] usually shunned" (Farrell, 2006, p. 204) but Gay as Folk normalized AIDS and made it known that this illness is not a death sentence nor ruins an individual's life. The television show analysed in Farrell's study greatly differed from other types of television, movies, and news print in the early part of the epidemic.

The news and television shows in the early years of the epidemic indicated that HIV/AIDS was a mystery to the medical community, but it appeared in pockets around the United States. These undergraduate students from Farrell's study would have experienced the paranoia associated with this illness when they were twelve or younger. They would have been going through their sexual education in the early 2000s, which may have emphasized how HIV/AIDS was spread and which groups were at risk of contracting the illness. When analysing the responses regarding sexual education from those partaking in the study, it is unclear if sexual education teachers would have emphasized that HIV/AIDS was an illness within the gay community or that it is transferred via bodily fluids. When the students were discussing AIDS amongst themselves, Farrell reported many misunderstandings - which could be blamed on poor sexual education as well as popular misunderstandings. These misconceptions included: transmitting the illness via kissing an infected person, that human spit could kill the HIV virus, and the most prominent - that contracting HIV as a gay man was almost unavoidable (Farrell, 2006). The news, television, and movies were shaming those with HIV which caused many individuals to hide their status (Hart, 2002). Hart (2002) indicates that in the first 20 years of the epidemic in America, the average person would have encountered an HIV positive 
individual without being aware of it (Hart, 2002).

Hart (2002) completed a study similar to Farrell's, as he watched 46 movies released in the first two decades of the AIDS epidemic in America with characters that had HIV in any form; diagnosed or living with it (Hart, 2002). Within these 46 movies, there were 111 characters that had HIV/AIDS, and Hart takes note of the stereotypes (Hart, 2002). The study was broken down into four categories: sex $-82.9 \%$ of characters were male (Hart, 2002, para. 11); age $-93.4 \%$ of characters were adult (Hart, 2002, para. 12); sexual orientation $-79.3 \%$ of characters were gay (Hart, 2002, para. 13); and race/ ethnicity - $71.7 \%$ characters were Caucasian (Hart, 2002, para. 14). The results of this study were overwhelmingly stereotypical towards white gay adult males (Hart, 2002). The statistics demonstrate that Hollywood was stereotyping gay men as carriers of this illness (Hart, 2002). When these statistics are compared to those from the CDC, they are incorrect (Hart, 2002). The first two decades of the epidemic prove that young adults that were heterosexual and of African or Hispanic American background were the most "at risk" populations for contracting HIV (Hart, 2002). Yet, of the 111 characters that were examined within Hart's study, only 8.8\% (Hart, 2002, para. 24) of characters within the 46 movies were male African or Hispanic Americans (Hart, 2002, para. 22). This study indicates that white gay men are the stereotypical character with AIDS, but Hart notes that higher risk groups are "Simultaneously and implicitly reassured through representations in other media offerings (including American movies about HIV/AIDS) that they likely are not really at risk at all" (Hart, 2006, para. 21).
Evidently, there is a lack of television shows and movies that aptly portray those with HIV/AIDS. Yet, Queer as Folk discusses HIV in a new way as gay characters with HIV are depicted as living normal lives and having loving relationships. The next section will discuss Rent, the musical, another format of information that expressed specific mentalities about those with HIV and how they chose to live the rest of their lives with this illness.

\section{Rent the Musical: Attitudes of HIV positive individuals.}

The musical Rent discusses how HIV positive individuals cope with the illness, which translates into how they decide to continue living their lives. There are many perspectives represented within the musical: Angel and Mimi decide to live their lives to the fullest, while Roger, already having lost someone to AIDS, tries to hide himself away, all the while creating a legacy in form of a song. Rent depicts the intertwining stories of seven fictional characters, four of which are HIV positive, and each having a completely different notion about their life. Valerie Lynn Schrader's article offers an analysis of the characters, script, and music lyrics (Schrader, 2009). S chrader (2009) notes that analysing this musical is worthwhile because "Theatre often has served to open the eyes of its audiences to problems or issues in society, and Rent reveals truths about HIV/AIDS, homosexuality, love for others, and tolerance" (Schrader, 2009, p. 25). This musical is subtler in relaying which characters have HIV/AIDS than the television show Queer as Folk, as the director J onathan Larson slowly reveals which characters have HIV as the musical goes on (Schrader, 2009). He does this mainly by the songs they sing and the dialogue (Schrader, 2009). 
The lyrics of the song "Another Day" indicate the first mentality of living life to the fullest, despite being diagnosed with HIV, as the song reads: "There is no past. I live this moment as my last. There's only us. There's only this. Forget regret, or life is yours to miss. No other road. No other way. No day but today" (Schrader, 2009, p. 27). In the play, these lyrics were sung at the AIDS support group, and again when Mimi sings them to Roger who has been isolating himself from others since being diagnosed with the illness (Schrader, 2009). An example of the second mentality of leaving a legacy before dying is seen in the subtle lines in the song "One Song Glory." Roger feels like he needs to write one song "before the virus takes hold" (Schrader, 2009, p. 26) because if he creates this song it will redeem him (Schrader, 2009). These two mentalities represent how these individuals chose to cope with the information regarding HIV/AIDS. The mentalities of these two characters are seen throughout the musical, but they both feel that they have baggage that must carry for the rest of their lives.

The characters, Mimi and Roger, juxtapose one another as they have opposite ideas about how to live their lives with this illness. Within the musical, they have a romantic relationship, but it is challenging for Roger to open up because he's "got baggage" (Schrader, 2009, p. 29). In the scene where this is explained, Mimi also divulges that she is "looking for baggage that goes with mine" (Schrader, 2009, p. 29). In that instant, the characters are telling one another that they are HIV positive. This dialogue between Mimi and Rodger is the first time that the audience begins to understand that Mimi is another character who is HIV positive, yet she acts unlike Roger (Schrader, 2009). The viewer may understand that Roger, particularly, has issues that no one would want to care for because he is now an outcast in society. Despite this musical not mentioning how these individuals are affected by the portrayal of AIDS within the media; one may assume that they are affected because these characters believe they have "baggage" which could be a by-product of the media's portrayal of HIV/AIDS. Similar to Queer as Folk, characters in Rent live normal lives but the audience is also able to see the hardship people face when they lose someone to HIV/AIDS - making this musical extremely innovative.

This musical is ground-breaking because there is a diverse group of characters that are affected with HIV who range in ethnicity and sexual orientation. It also depicts that those with HIV have an array of attitudes surrounding their situation, and have diverse ways they cope. Angel is a cross dresser, while Tom Collins is a professor, and they are both embracing love and life together (Schrader, 2009). The status of these characters does not define their lives, and even when Angel dies as a result of AIDS, everyone at the funeral spoke about his amazing qualities (Schrader, 2009). This musical also takes into account that there are people living with AIDS much longer than they were technically supposed to. There is a scene that takes place at the AIDS life support group where one member expresses, "I'm used to relying on intellect. But I try to open up to what I don't know, because reason says I should have died three years ago" (Schrader, 2009, p. 26). This character explains to the group that his T-cell count was low and he basically did not know when his life would end due to the lack of information being produced by modern doctors, as they did not know either (Schrader, 2009). This dialogue brings forth 
the mentalities of those who have HIV, in a time when there was so much uncertainty about it even within the medical community. The content within the musical indicates to its audience what it is like to be diagnosed with HIV, and the viewers can see the multiple ways people cope with the illness. This medium is much different than the others that have been discussed thus far, as it presents a more realistic view of the topic. This musical was made into a movie in 2005, and could reach a larger audience of people to allow a better understanding of HIV/AIDS in the new millennia.

\section{Conclusion}

In conclusion, the HIV virus and AIDS disease struck the North American continent at the end of the 1970s, and there was little known about this illness, other than the fact that it affected the gay population first. When the disease was broadcast to North American societies, primarily in 1985, it created a panic as there was no cure for this virus and it was only appearing in a specific group of people - gay men. When following the epidemiology, infected individuals were spreading the disease unknowingly, such as Gaetan Dugas (Shilts, 1987). Television shows and Hollywood movies were helping to propel the ideas of the "gay plague" as these corporations were creating plot lines with white, gay men who were HIV positive instead of informing their audiences that everyone was at risk (Hart, 2002). Many heterosexual people were made to feel invincible because they learned they were not at risk through mainstream television shows and movies (Hart, 2002). By the turn of the century, CDC statistics were noting that that the gay population was not the sole "at risk" group any longer, yet they were still portrayed as such in all forms of media (Hart, 2002). This paper articulated that within the mass of incorrect information within the media, there was an attempt to combat the generalized misconceptions. Selected films, television shows, and musicals portrayed the more realistic facts about those living with HIV/AIDS, that spread to a large audience of people to clarify the mistakes that were made in the early years of the epidemic.

\section{References}

Brodie, M., Hamel, E., Brady, L. A., Kates, J ., \& Altman, D. E. (2004). AIDS at 21: Media coverage of the HIV epidemic 1981-2002. Columbia J ournalism Review, 42(6), A1.

Burkett, E. (1995). The Gravest Show on Earth: America in the Age of AIDS. New York: Park Avenue South.

Family in AIDS Case Quits Florida Town After House Burns (1987, August 30), New York Times. Retrieved from

http://www.nytimes.com/1987/08/30/ us/family-in-aids-case-quits-floridatown-after-house-burns.html

Farrell, K. P. (2006). HIV on TV: Conversations with young gay men. Sexualities, 9(2), 193-213.

Gallagher, J . (2014, O ctober 3). Aids: Origin of pandemic 'was 1920s Kinshasa'. $B B C$. Retrieved from http://www.bbc.com/news/health$\underline{29442642}$

Gallagher, J . (2016, O ctober 26). HIV Patient Zero cleared by science. BBC. R etrieved from http://www.bbc.com/news/health37767179

Hart, K. R. (2002). Representing men with HIV/AIDS in American movies. 
J ournal of Men's Studies, 11(1), 77. Retrieved from

http://ezproxy.library.dal.ca/login? url =http://search.proquest.com.ezproxy .library.dal.ca/docview/222640331?a ccountid $=10406$

Locatelli, S., \& Peeters, M. (2012). Crossspecies transmission of simian retroviruses: how and why they could lead to the emergence of new diseases in the human population. Aids, 26(6), 659-673.

Netburn. D. (2016, October 26). How scientists proved the wrong man was blamed for bringing HIV to the U.S. Los Angeles Times. Retrieved from

http://www.latimes.com/science/scie ncenow/la-sci-sn-hiv-genetic-history20161026-snap-story.html

Pepin, J . (2011). The origins of AIDS. New York: Cambridge University Press.

Schrader, V. L. (2015). " No Day But Today:" Life Perspectives of HIVPositive Individuals in the Musical Rent. Communication and Theater Association of Minnesota J ournal, 36(1), 3.

Shilts, R. (1987). And the band played on: People, politics, and the AIDS epidemic. New York: St. Martins. 